mines and quarries are of high importance. Among the many places where modern research has been aptly utilised, we may mention E. B. Bailey's preference (p. 9) for ascribing a continental origin to the Old Red Sandstone, and his comparison of the "cornstones" with the kankar of tropical Africathe original Indian examples might well have received mention. The alleged unconformity between the Barren Measures and the productive Coal Measures is regarded (p. 61) as improbable, owing to C. T. Clough's observations, published in I9Io. G. W. Lee contributes a chapter of sixteen pages on the palæontology of the Carboniferous rocks of the district, from which it is pleasant to see how much we owe to members of the Geological Society of Glasgow. The interesting paragraphs (p. 94, \&c.) on the life-zones of the system show how difficult it is to define, to the satisfaction of palæobotanists and palæozoologists alike, the lower limit of the Upper Carboniferous series. The base of the upper, or Visean, division of the Avonian, or Lower Carboniferous, lies somewhere below the Hollybush Limestone in the Calciferous Sandstone stage. All the "Carboniferous Limestone" stage near Glasgow is thus correlated with beds high up in the "Carboniferous Limestone " of southern England.

E. B. Bailey (pp. I24-50) treats of the petrology of the igneous rocks with enthusiastic thoroughness. We are glad to note the use of "alkali" as an adjective, rather than " alkaline," for types of rocks rich in sodium or potassium. Nepheline has now been found in several of these in the Glasgow district, notably in the "alkali gabbro" of Lennoxtown. The influence of Rosenbusch in establishing rockspecies has spread to the Central Valley of Scotland, since a rock, already described as a theralite, becomes thus qualified (p. 135):-" In these characters it approaches much more closely the bekinkinites of Madagascar, which are a highly melanocratic type of ijolite." We regret to read that several other ultrabasic rocks of the area "have a composition which places them near to the bekinkinites," so that the way lies open for at least one new name, indicating, as must so often happen, nearness rather than identity. May we quarrel also with the word " macroporphyritic," which does not quite represent the author's meaning? It is interesting to find Abich's term " trachydolerite" --a very bad one from the point of view of rock-structure-revived for rocks that might surely be styled trachytic andesites. Harker's " mugearites," those interesting fine-grained types with orthoclase, oligoclase, augite, and often olivine, are recognised in the Carboniferous rocks near Glasgow. The discussion and diagram of the composition of the quartz-dolerites (p. I46) are of especial interest.

The chapters on the origin of local topographic features, including details of recession and rivercapture on the escarpment of the Campsie Fells, bear further witness to the thoroughness of the Geological Survey work. These pages could be read with appreciation by persons who have never seen the district, and they will tempt many from the smolse of the great city into the gaps in the highland border that open up another world.

The Scottish branch also issues a memoir, by E. H. Cunningham Craig, W. B. Wright, and E. B. Bailey, on the "Geologv of Colonsay and Oronsay, with Part of the Ross of Mull " (rorr, price 2s. 3d.) The one-inch geological map issued in connection with it (Sheet 35, price 2s. 6d.) is mainly concerned with the Atlantic Ocean, and Oronsay lies beyond it on the south. Plate $\mathrm{i}$. of the memoir, however, completes the island group. Most of the sedimentary rocks are believed to be representatives of the Torridon Sandstone. There is a considerable range of igneous rocks, and W. B. Wright and E. B. Bailey describe and illustrate an attractive example of the interaction of an ultrabasic hornblende-rock with included blocks of quartzite (p. 29). The quartzite, during solution, has led to a local concentration of alkalies. Many of the blocks, "surrounded by a magma which is overwhelmingly hornblendic, are actually replaced by alkali felspars and quartz." Tectonic features are described in detail, and we wish that James Hutton could again come to life to see how, in this and other instances, physical geology holds its own in Scotland. The glaciation of Colonsay took place from the east, and a map (p. 6r) shows the course of boulders over the island from the mainland beyond Loch Awe. A pre-glacial rock-shelf, due to marine erosion, with accompanying cliffs, is traceable as high as $135 \mathrm{ft}$. above high-water mark (p. 62). E. H. Cunningham Craig in part ii. describes part of the Ross of Mull, and supports Judd's view that the great mass of granite is of later Palæozoic age. Both in this memoir and in that on the Glasgow district the petrographic details owe much to the advice and notes of J. S. Flett.

A third Scottish memoir, by ten authors, deals with Knapdale, Jura, and North Kintyre (rgrr, price $3 s$. .). The immense part played by quartzite in Jura is well brought out on the accompanying map, Sheet 28 . The term "vitreous quartzite" (p. 99) seems a little misleading, like the "glassy felspar" of older writers. This series in Jura may be $15,000 \mathrm{ft}$. in thickness (p. 106). A pleasant feature of the memoir is the introduction by J. B. Hill, where the geological structure and the raised beaches are concisely brought into relation with the human interests of the district.

G. A. J. C.

\section{DISCUSSIONS OF CLIMATOLOGY.}

A DISCUSSION by Dr. A. B. Rosenstein of the conditions of temperature in central and southern Spain is published in vol. xxxiv. (part iii., I9II) of Aus dem Archiv der deutschen Seewarte, based on observations of the last twenty years of the last century, and including a longer series for Lisbon, San Fernando, Coimbra, and Madrid. The last four stations represent essentially different climatological types, as previously pointed out by Hellmann. The author deals with the observations in considerable detail (twenty-seven tables), but we can only very briefly refer here to one or two of the results. The amplitude of the daily range, being chiefly dependent upon the season, is smallest in winter (December) at the above-mentioned stations (at San Fernando in April), and greatest in summer (August); in the latter season the mean daily range at Madrid is $13^{\circ} 8^{\circ} \mathrm{C}$., twice that at Lisbon and San Fernando. With reference to the yearly range, one of the tables shows the deviations of the monthly from the yearly means, the sum of the greatest plus or minus monthly departures being given as the expression of the mean yearly oscillation. The stations are divided into three groups: (I) coastal, where the aggregate mean yearly oscillation is between $1 x^{\circ} 5^{\circ}$ and $15^{\circ} 3^{\circ} \mathrm{C}$.; (2) more inland, oscillation between $15^{\circ} 9^{\circ}$ and $18.2^{\circ}$; and (3) central tableland and plateaux, oscillation between I $89^{\circ}$ and $20^{\circ} 1^{\circ}$. This useful paper closes with tables showing the interdiurnal variability of temperature at Madrid (yearly mean $I^{\circ} 5^{\circ}$ C.) and San Fernando $\left(\mathrm{I}^{\circ} \mathrm{O}^{\circ}\right)$.

A discussion of "The rainfall of Jamaica from about I870 to end of I909," with monthly and annual maps, has been published recently by Mr. Maxwell Hall, Government meteorologist. It includes means from a large number of stations, so far as observations were available, and general averages for each of the No. 2218 , VOL. 89] 
several sections into which the island is divided for meteorological purposes. While the rainfall is fairly well distributed over the year, it is rather heavy in each division in May, June, September, and October; the north and north-east divisions have winter rains in November and December, and the north-east and west-central divisions have summer rains in July and August. The annual average for the whole island is $7 \mathrm{r}^{\circ} 77$ inches, maximum $90^{\circ} 61$ inches in 1886 , minimum $45^{\circ} 18$ inches in $187^{2}$. The heaviest falls occur in the north-east division, where the aggregate average is $93^{\circ} 5^{2}$ inches, the annual amounts exceeding roo inches in many years. Some remarkable flood rains in twenty-four hours are reported during cyclonic disturbances, frequently exceeding 20 inches, and on one occasion (November 6, I909) exceeding 30 inches on the Blue Mountain range. A table of the mean diurnal range at Kingston shows that the rainfall increases more or less regularly from the early morning until $3 \mathrm{~h}$. and $4 \mathrm{~h}$. p.m., after which it decreases to a minimum at midnight. The work is a valuable addition to our knowledge of the rainfall in the West Indies.

Dr. O. L. Fassig has sent us a useful paper on "The Climate of Porto Rico," chiefly based upon observations of the U.S. Weather Bureau during the years I899-1909. The island, which is the most eastern of the Greater Antilles, and one of the most favoured regions within the tropics, has always been primarily devoted to the pursuit of agriculture. It has an equable and comfortable climate; the mean annual temperature at forty selected stations (combining all the records) is given as $76^{\circ} 4^{\circ}$, February $73^{\circ} 3^{\circ}$, August $79^{\circ} \mathrm{I}^{\circ}$, absolute maximum $103^{\circ}$ in August, minimum $43^{\circ}$ in February and March. The mean values naturally vary somewhat at individual coast and mountain stations; there is a fairly constant difference of $6^{\circ}$ to $8^{\circ}$ between the coast temperatures and those of the higher inland stations throughout the year. The average annual rainfall for the whole island is $77^{\circ} 30$ inches; the amounts vary greatly from year to year, e.g. $93^{\circ} 72$ inches in 1901 , and only $64^{\circ}$ I 8 inches in 1907 , while in the Luquillo mountains, where rainfall is heaviest, the average annual amount exceeds 135 inches, and along portions of the south coast it is less than 40 inches. The average number of rainy days is 160 for the island as a whole; there are no well-defined wet and dry seasons. Porto Rico is comparatively free from storms of all kinds; the centre of a hurricane has only passed over the island three times in forty vears, all in the month of August.

\section{BIRD NOTES}

THE Agricultural Research Institute at Pusa, Bengal, has taken up the subject of the food of Indian birds, and issued a preliminary report (Mem. Dept. Agric. India, Entomology, vol. iii., January, I9I2) by Mr. C. W. Mason, edited and supplemented by Mr. H. Maxwell Lefroy. To a great extent the report is a compilation of extracts from the writings of Indian ornithologists relating to the food of birds, but it also includes an analysis of the contents of the stomachs of a considerable number of specimens (1325) which have been examined in the laboratory. It is very largely a confession of ignorance, as at present little is known with certainty as to the economic utility or harmfulness of Indian birds, and it is consequently impossible in most cases to make definite statements. Mr. Mason is, however, of opinion that as weed-killers-by consuming seedsbirds are of no value at all in India. Such birds "may keep weeds down to a certain extent, but this is of minor importance in a country where labour is NO. 22 I8, VOL. 89 ] cheap and where farming is not practised on such intensive lines as elsewhere. Even in intensive cultivation we cannot rely on weeds being kept down by birds, and the expense of cultivation to eliminate weeds is, I believe, not reduced in the slightest by the action of birds.'

It is noteworthy that although hawks and owls are regarded, in the main, as beneficial, yet they are considered to be undoubtedly harmful on account of destroying insectivorous shrewmice, toads, frogs, and lizards.

In the February number of Witherby's British Birds Mr. Ogilvie Grant points out that the partridge possesses two seasonal plumage-changes-one in the male and the other in the female-which have been hitherto overlooked. During the autumnal moult, lasting from July to September, the cock develops on the sides of the head and neck light umber-brown feathers marked by narrow buff, black-bordered shaft-stripes; this so-called eclipse-plumage replacing for about two months the normal black-waved grey feathers. In the hen during May the ordinary plumage of the same parts, as well as of the back, is replaced by sandy-brown feathers mottled or barred with black, and having buff shaft-stripes, and usually a terminal spot of the same hue. This breeding plumage, which is retained until September, produces a mottled appearance, especially round the neck, which is held to be protective to the sitting bird.

The April number of the same journal contains a supplementary record by the editor of the dispersal of little auks over the inland districts of England due to the stormy weather which prevailed in the early part of January. The birds seem to have struck the coast in greatest numbers between Norfolk and the Firth of Forth, those reported from the western and midland counties having probably travelled from the east. Although the number of birds appears to have been fewer than in the visitation of 1895 , they seem to have been spread over a wider area of country.

Notes on the breeding of the white-headed stilt in a swamp near Melbourne are contributed by Mr. C. French to the January numbers of The Emu and The Victorian Naturalist. This is believed to be the first record of the breeding of these beautiful birds in Victoria. Unfortunately, the swamp dried up before the nesting was completed, thus causing many of the eggs and young to be deserted. The nests, which were from io to ${ }_{5} \mathrm{ft}$. apart, and were made of dried water-plants, were constructed on tussocks of sea crab-grass (Salicornia); the first eggs were laid early in October.

In his review of Norfolk ornithology for I9II, published in The Zoologist for April, Mr. J. $\mathrm{H}$. Gurney suggests that the breeding of a pair of bitterns in the county may have been due to the drying up of some of the Dutch swamps by the unusual heat and dryness of the summer. Another event was the nesting of a pair of curlews near King's Lynn.

We have received a copy of the second number of The Austral Avian Record, a new journal, edited by Mr. G. M. Mathews, and published by Messrs. Witherby and Co., primarily devoted to the study of Australian birds. This number contains a long list of new subspecies and other addenda to the Australian fauna, which from internal evidence is clearly from the pen of the editor, although there is no other indication of its authorship.

The birds of Lower Egypt form the subject of an article by $\mathrm{Mr}$. C. B. Ticehurst in the February issue of The Zoologist; Mr. M. J. Nicoll is also writing on the same subject in The Ibis. 